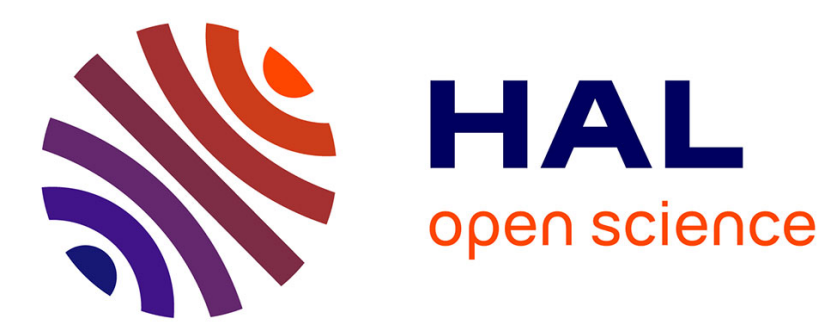

\title{
Speciation Studies of Iron (III) with (Poly)phosphonate Ligands: The Case of EDTMP (EthylenediamineTetramethylene Phosphonic Acid)
}

Constantin Mateescu, Ecaterina Princz, Gilles Bouet, Mustayeen A. Khan

\section{To cite this version:}

Constantin Mateescu, Ecaterina Princz, Gilles Bouet, Mustayeen A. Khan. Speciation Studies of Iron (III) with (Poly)phosphonate Ligands: The Case of EDTMP (EthylenediamineTetramethylene Phosphonic Acid). Phosphorus, Sulfur, and Silicon and the Related Elements, 2006, 181 (4), pp.947958. 10.1080/00207450500272230 . hal-03230393

\section{HAL Id: hal-03230393 \\ https://univ-angers.hal.science/hal-03230393}

Submitted on 21 May 2021

HAL is a multi-disciplinary open access archive for the deposit and dissemination of scientific research documents, whether they are published or not. The documents may come from teaching and research institutions in France or abroad, or from public or private research centers.
L'archive ouverte pluridisciplinaire HAL, est destinée au dépôt et à la diffusion de documents scientifiques de niveau recherche, publiés ou non, émanant des établissements d'enseignement et de recherche français ou étrangers, des laboratoires publics ou privés. 
archives-ouvertes

\section{Speciation Studies of Iron (III) with (Poly)phosphonate Ligands: The Case of EDTMP (EthylenediamineTetramethylene Phosphonic Acid)}

Constantin Mateescu, Ecaterina Princz, Gilles Bouet, Mustayeen A. Khan

\section{To cite this version:}

Constantin Mateescu, Ecaterina Princz, Gilles Bouet, Mustayeen A. Khan. Speciation Studies of Iron (III) with (Poly)phosphonate Ligands: The Case of EDTMP (EthylenediamineTetramethylene Phosphonic Acid). Phosphorus, Sulfur, and Silicon and the Related Elements, Taylor \& Francis, 2006, 181 (4), pp.947-958. 10.1080/00207450500272230 . hal-03230393

\section{HAL Id: hal-03230393 \\ https://hal.univ-angers.fr/hal-03230393}

Submitted on 19 May 2021

HAL is a multi-disciplinary open access archive for the deposit and dissemination of scientific research documents, whether they are published or not. The documents may come from teaching and research institutions in France or abroad, or from public or private research centers.
L'archive ouverte pluridisciplinaire HAL, est destinée au dépôt et à la diffusion de documents scientifiques de niveau recherche, publiés ou non, émanant des établissements d'enseignement et de recherche français ou étrangers, des laboratoires publics ou privés. 


\section{Speciation Studies of Iron (III) with (Poly)phosphonate Ligands: The Case of EDTMP (Ethylenediamine- \\ Tetramethylene Phosphonic Acid)}

\section{Constantin Mateescu}

Banat's University of Agricultural Sciences and Veterinary Medicine,

Faculty of Food Processing Technology, Timişoara, Romania

\section{Ecaterina Princz}

Institute of Chemistry Timisoara of Romanian Academy,

Timişoara, Romania

\section{Gilles Bouet}

\section{Mustayeen A. Khan}

Université d'Angers, Faculté de Pharmacie, Chimie de Coordination,

Angers, France

The complex formation equilibrium of ethylenediaminetetramethylenephosphonic acid (EDTMP, $H_{8} L$ ) with iron (III) has been studied potentiometrically at $25^{\circ} \mathrm{C}$ and an ionic strength of $0.2 \mathrm{M}(\mathrm{NaCl})$. The successive protonation constants of ligand EDTMP and the complex formation constants were determined with the PSEQUAD program. Keeping in view the biological studies, the speciation in the system $\mathrm{Fe}_{\mathrm{e}}$ pFe values are was calculated and drawn with the HySS computer program, and

Keywords EDTMP; Fe (III); HySS; potentiometry; PSEQUAD; speciation

\section{INTRODUCTION}

Magnetic Resonance Imaging (MRI) has become one of the primary imaging modalities in modern medicine. With the widespread use of MRI, there is an increasing demand for efficient paramagnetic contrast agents used to enhance the differences between normal and diseased tissue or to indicate specific organ functions. Complexes of some paramagnetic transition metal and rare earth ions have been considered as potential contrast agents. ${ }^{1,2}$ The complexes mentioned Received December 9, 2004; accepted April 12, 2005.

Address correspondence to Mustayeen A. Khan, University d'Angers, Faculté de Pharmacie, Chimie de Coordination, SONAS EA 921, 16, Boulevard Daviers, F-49100 Angers,
France. E-mail: mustayeen.khan@univ-angers.fr 
in the literature $\mathrm{e}^{3-10}$ are polyaminopolycarboxylate coordination compounds.

Polyaminopolycarboxylates (PAPC), represented first of all by ethylenediamine- $N, N, N^{\prime}, N^{\prime}$-tetraacetate (EDTA), have been extensively characterized with respect to analytical and coordination chemistry. The polyaminopolyphosphonates (PAPP) were synthesized for thistry. time by Schwarzenbach and colle trial purposes such as a scale inhibitor for oil drilling and geothermal power plants. However, their properties are not so well understood as power plants. However, their
compared to those of PAPC.

These PAPP have high first-protonation constants relative to those of corresponding PAPC. In the case of ethylenediamine- $N, N, N^{\prime} N^{\prime}$ tetramethylenephosphonate $\left(\mathrm{EDTMP}^{8-}\right.$ ) thermodynamic ${ }^{12}$ and ${ }^{31} \mathrm{P}$ NMR studies ${ }^{12,13}$ revealed that protonation equilibria are rather complicated. On the other hand, the first protonation occurs on the nitrogen atom and forms a hydrogen bond between both nitrogen atoms $\left(\mathrm{NH}^{+}\right.$ $\cdots N)$. The second protonation predominantly occurs on the phosphonate oxygen atom because of the decrease in the basicity of an unprotonated nitrogen atom due to the formation of a hydrogen bond, and both of the nitrogen atoms are protonated at the third protonation.

This work is part of a wider project seeking to compare and/or correlate the physical parameters of different metal-ligand and/or cortermined with recent computer programs, and hence, under identical conditions. This article presents the results of some aqueous solution studies concerning the formation, stability, and speciation of the coorstudies concerning the formation, stability,
dination compounds of $\mathrm{Fe}$ (III) with EDTMP.

\section{EXPERIMENTAL}

Potentiometric titrations were performed with a CG 841 Schott pHmeter equipped with a glass electrode $\mathrm{N} 6280$. The $\mathrm{pH}$ electrode was calibrated using two standard buffer solutions. All calibrations and titrations were carried out in a glass vessel $\left(25 \mathrm{~cm}^{3}\right)$ under a $\mathrm{CO}_{2}$ free nitrogen atmosphere to avoid any conder a $\mathrm{CO}_{2-}$ rature was regulated at $25.0 \pm 0.1^{\circ} \mathrm{C}$, with carbon dioxide. The $\mathrm{C}$, and an ionic strength of 0.2 which a which consisted of $0.078 \mathrm{M} \mathrm{KOH}$ and $0.120 \mathrm{M} \mathrm{NaCl}$, to minimize the ionic strength change during titration.

The potentiometric equilibrium studies were made with ligand solutions at different concentrations: in the absence of ferric ions, and then in the presence of metal ions with the $\mathrm{M}: \mathrm{L}$ ratios $1: 1,1: 2$, and $1: 4$, respectively. The $\mathrm{pH}$ data were obtained after the addition of $0.100 \mathrm{~cm}^{3}$ increments of a standardized $\mathrm{KOH}$ solution.
At low values of a $\mathrm{pH}$, a solid phase appears in the solution in the presence of ferric ions. This phase disappeared at $\mathrm{pH} 2.50$ in a solution with an M:L ratio of 1:4, at $\mathrm{pH} 4.76$ in a solution with an M:L ratio of 1:2, and at $\mathrm{pH} 5.79$ in a solution with an M.L ratio with an M:L ratio of 1:2, of overall stability constants, only the $\mathrm{pH}$ values for clo the calculation considered. At $\mathrm{pH}$ values between 5 to 8 , the equilibrium was attained slowly, and about 5 min was required for each point of the titration.

A stock solution of $0.01784 \mathrm{M} \mathrm{Fe}^{3+}$ in $2.10^{-2} \mathrm{M} \mathrm{HCl}$ was prepared from $\mathrm{FeCl}_{3}$ and a standardized $\mathrm{HCl}$ solution. The titrant solution was prepared from $\mathrm{KOH}$ and it was standardized with potassium hydrogeniodate.

The ligand was synthesized in the laboratory, ${ }^{14}$ and the purity of ligand was confirmed by titration with a standardized $\mathrm{ZnSO}_{4}$ solution in the presence of Eriochrom black $\mathrm{T}$ at a buffered value of $\mathrm{pH}=10$.

The protonation constants of the ligand and the overall stability constants of the various ferric complexes formed in an aqueous solution were determined from the titration data with the Fortran computer program PSEQUAD. ${ }^{15}$ Species distribution diagrams were computed from the overall formation constants with HySS computer program ${ }^{16}$

The $\mathrm{pK}_{\mathrm{w}}$ value for the aqueous system, defined as $-\log \left[\mathrm{H}^{+}\right] \cdot\left[\mathrm{OH}^{-}\right]$ at the ionic strength employed, was 13.74 at $25^{\circ} \mathrm{C} .^{17}$

\section{RESULTS AND DISCUSSIONS}

The reactant concentrations used in these studies, along with the $\mathrm{pH}$ ranges on which the calculations are based, are reported in Table I. The measurements made at acidic $\mathrm{pH}$, where the solid complexes of $\mathrm{Fe}$ (III) were separated, were not included in the final calculations.

The titration curves of the ligand, in the absence or in presence of different concentrations of ferric ions, indicate the formation of ferric chelates containing hydrogen ions in addition to the metal. At a higher

TABLE I Summary of the Titration Data Used for Calculating Formation Constants

\begin{tabular}{|c|c|c|c|c|c|}
\hline System & $\begin{array}{c}\begin{array}{c}\mathrm{C}_{\mathrm{Fe}} \\
\left(\mathrm{mmol} \cdot \mathrm{dm}^{-3}\right)\end{array} \\
\end{array}$ & $\begin{array}{c}\mathrm{C}_{\mathrm{L}} \\
\left(\mathrm{mmol} \cdot \mathrm{dm}^{-3}\right)\end{array}$ & $\begin{array}{c}\mathrm{C}_{\mathrm{H}} \\
\left(\mathrm{mmol} \cdot \mathrm{dm}^{-3}\right)\end{array}$ & $\begin{array}{l}\mathrm{pH} \text { range used for } \\
\text { the calculation }\end{array}$ & $\mathrm{n}^{a}$ \\
\hline $\begin{array}{l}\text { proton-edtmp } \\
\left(25^{\circ} \mathrm{C}\right)\end{array}$ & & $\begin{array}{l}1.936 \\
0.968\end{array}$ & & $\begin{array}{l}2.125-11.317 \\
2.515-11.120\end{array}$ & $\begin{array}{l}61 \\
32\end{array}$ \\
\hline & 1.784 & 1.936 & 2.000 & $5.787-11.161$ & $\begin{array}{l}32 \\
23\end{array}$ \\
\hline $\mathrm{Fe}$ (III)-edtmp & 0.856 & 1.936 & 0.960 & $4.763-11.327$ & 35 \\
\hline$\left(25^{\circ} \mathrm{C}\right)$ & 0.428 & 1.936 & 0.480 & $2.505-11.404$ & 54 \\
\hline
\end{tabular}

${ }^{a} \mathrm{n}$ represents the number of experimental observations in each titration. 
$\mathrm{pH}$, all the acidic chelates go over to the "normal" chelates from which all the dissociable hydrogens have been displaced.

The protonation constants of EDTMP were calculated by fitting the program $^{15}$. The initial of for the free ligand to the PSEQUAD proton obtained in the form of overal protonation constants $\beta_{i}=\left[\mathrm{H}_{\mathrm{i}} \mathrm{L}\right] \cdot[\mathrm{L}]^{-1} \cdot[\mathrm{H}]^{-\mathbf{i}}$. Table II gives the protonation constants of EDTMP-our data and literature values-calculated as $\mathrm{K}_{\mathrm{i}}^{\mathrm{H}}=\frac{\left[\mathrm{H}_{\mathrm{i}} \mathrm{L}\right]}{\left[\mathrm{H}_{\mathrm{l}-1} \mathrm{~L}\right] \cdot[\mathrm{H}]}$, taking into account that $\beta_{\mathrm{i}}=\prod_{i=1}^{i=6} \mathrm{~K}_{\mathrm{i}}^{\mathrm{H}}$. As pointed out by Motekaitis and colleagues, ${ }^{22}$ the values reported
before 1976 may contain a considerable of an impure reagent or an imperfect analysis of data. As an example, until 1976 the protonation constants of calculated by She protonation constants of EDTMP were generally calculated by Schwarzenbach's and Ackermann's ${ }^{26}$ graphical method with a small modification based on the assumption that the number of protonated species dominant within a buffer region is restricted. After 1976 an efficient computer program was developed for these calculations. Details about the protonation of EDTMP can be found in the
literature. ${ }^{12,24,27}$

The stability constants of the various species formed in the aqueous solution were obtained from the experimental data of titrations of a solution with a different ligand: ferric ions ratios, using the sams of a gram. As for the ligand, the initial computation was of the overall stability, the initialcomp

TABLE II Protonation Constants of the Ligand (EDTMP) $\left(25^{\circ} \mathrm{C}, \mathrm{I}=\right.$ $0.2 \mathrm{M}$ NaCl) Compared With the Literature Data

\begin{tabular}{|c|c|c|c|c|c|c|c|c|c|}
\hline \multirow[b]{2}{*}{$\mathrm{pK}_{\mathrm{i}}$} & \multirow[b]{2}{*}{ This work ${ }^{a}$} & \multicolumn{8}{|c|}{ Literature data } \\
\hline & & $18^{b}$ & $19^{b}$ & $20^{c}$ & $21^{c}$ & $22^{b}$ & $23^{b}$ & $24^{b}$ & $25^{d}$ \\
\hline $\mathrm{pK}_{1}$ & $11.33(2)$ & 10.21 & 10.60 & 12.10 & 10.68 & 12.99 & 10.60 & 13.0 & 9.64 \\
\hline $\mathrm{pK}_{2}$ & $9.14(4)$ & 9.91 & 9.22 & 10.18 & 9.21 & 9.78 & 10.48 & 9.85 & 7.69 \\
\hline $\mathrm{pK}_{3}$ & $7.44(5)$ & 8.02 & 7.43 & 8.08 & 7.66 & 7.94 & 9.27 & 7.87 & 6.27 \\
\hline $\mathrm{pK}_{4}$ & $6.06(5)$ & 7.14 & 6.63 & 6.54 & 6.95 & 6.42 & 7.39 & 6.40 & 5.04 \\
\hline $\mathrm{pK}_{6}$ & $4.85(6)$ & 5.25 & 6.18 & 5.23 & 5.64 & 5.17 & 5.63 & 5.12 & 2.86 \\
\hline $\mathrm{pK}_{6}$ & $1.66(22)$ & 4.41 & 5.05 & 3.00 & 3.72 & 3.02 & 3.80 & 2.96 & 1.12 \\
\hline $\mathrm{pK}_{7}$ & - & 2.77 & 2.72 & - & 1.50 & 1.33 & 2.73 & $<1$ & $<1$ \\
\hline $\mathrm{pK}_{8}$ & - & 2.45 & 1.46 & - & - & - & 2.43 & $<1$ & $<1$ \\
\hline
\end{tabular}

${ }^{a}$ Fitting (average difference between experimental and calculated titration curves expressed in $\mathrm{cm}^{3}$ of titrant) 0.0148 ; number of points 93 ; values in parenthesis are ${ }^{6} 25^{\circ} \mathrm{C}, I=0.1 \mathrm{M}$ (

$\mathrm{c}_{25^{\circ}} \mathrm{C}, \mathrm{I}=0.1 \mathrm{M}\left(\mathrm{KNO}_{3}\right)$

${ }^{d} 25^{\circ} \mathrm{C}, I=0.15 \mathrm{M}(\mathrm{NaCl})$ which the subscript $m$ stands for metal, $l$ for ligand, and $h$ for proton. For these calculations, the fact that ferric ions form several hydrolytic species in an aqueous solution was taken into account. There is a disagreement on the subject of their values in the literature. We have used the values reported by Achour and colleagues, ${ }^{28}$ which are considered reliable. The hydrolysis constants of the $\mathrm{Fe}^{3+}$ ions used in this wered are

$\log \beta_{[\mathrm{FeOH}] /(\mathrm{Fe}][\mathrm{OH}])}=11.29, \quad \log \beta_{\left[\mathrm{Fe}(\mathrm{OH})_{2}\right] /\left([\mathrm{Fe}][\mathrm{OH}]^{2}\right)}$

$=21.74, \quad \log \beta_{\left[\mathrm{Fe}_{2}(\mathrm{OH})_{2}\right] /\left([\mathrm{Fe}]^{2}[\mathrm{OH}]^{2}\right)}=24.84$.

To examine the experimental data, the protonation curves of the ligand obtained ince of iron (III) were compared with the reference curves obtained in its absence (Figure 1). All these curves represent variation of the average ligand protonation number $(\overline{\mathrm{r}})$ as a function of $\mathrm{pH}$ :

$$
\overline{\mathbf{r}}=\frac{\mathrm{C}_{\mathrm{H}}+8 \cdot \mathrm{C}_{\mathrm{L}}-\mathrm{C}_{\mathrm{OH}}+[\mathrm{OH}]-[\mathrm{H}]}{\mathrm{C}_{\mathrm{L}}}
$$

where $\mathrm{C}_{\mathrm{H}}, \mathrm{C}_{\mathrm{L}}$, and $\mathrm{C}_{\mathrm{OH}}$ are the total concentrations of protons (added with a stock solution of iron), ligand, and $\mathrm{KOH}$ titrated, respectively. indicating that EDTMP at high $\mathrm{pH}$, the curve levels off at about 1 indicating that the last proton cannot be removed. Below $\mathrm{pH}=3$, the curve levels off at about 6 , and this indicates that 6 protons have been

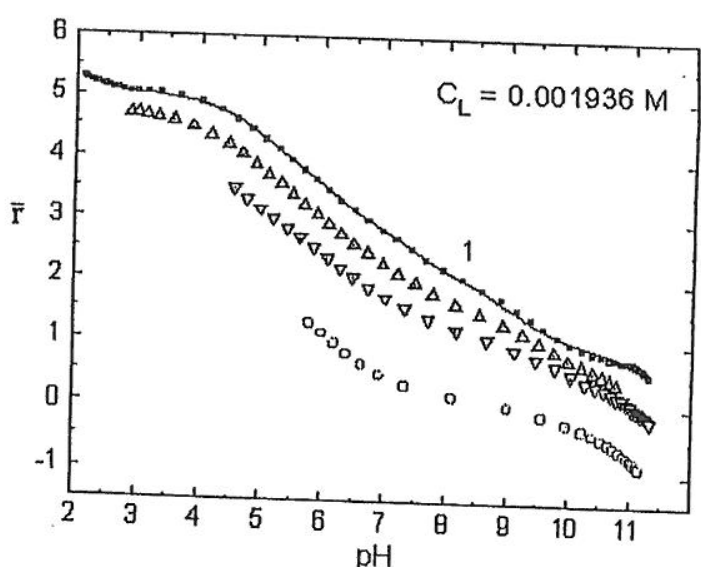

FIGURE 1 Protonation curves for (1) ligand (solid line represent calculated triangle) ligand: $\mathrm{Fe}(\mathrm{III})=4: 1$ ) $=1: 1$, (down triangle) ligand: $\mathrm{Fe}(\mathrm{III})=2: 1$, (up data obtained at $25^{\circ} \mathrm{C}$ and 


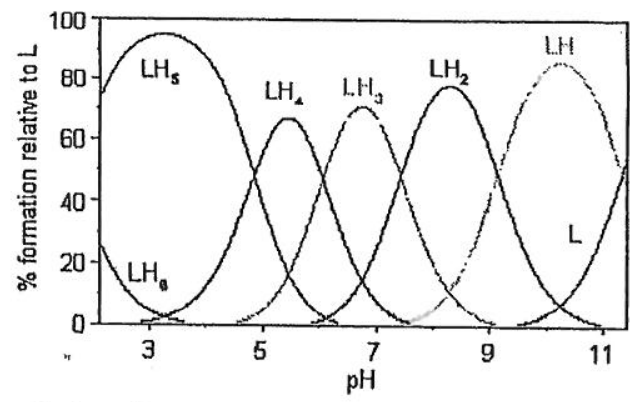

FIGURE 2 Speciation diagrams of the ligand, calculated for $\mathrm{C}_{\mathrm{L}}=0.001936$ $\mathrm{M}$, at $25^{\circ} \mathrm{C}$ and $I=0,2 \mathrm{M}(\mathrm{NaCl})$

added to the ligand. These 6 protonation constants have been determined in this study. The agreement between the calculated function and experimental data is good, which confirms the chosen model. The plateau at $\vec{r}=5$ and a pH between 3 to 4 indicates that the species with 5 protons is the dominating species. The speciation diagrams of the ligand, in Figure 2, calculated with HYSS ${ }^{16}$ confirm that $\mathrm{LH}_{5}^{3-}$ dominates between $\mathrm{pH}$ values 3 to 4 . Potentiometric, protonation, and speciation curves indicate that not all the phosphonate groups are deprotonated until $\mathrm{pH}$ values around 10 to 11 are reached.

Westerback and colleagues ${ }^{19}$ reported the formation and protonation constants of EDTMP complexes with ferric ions, and their values agree with our data, as shown in Table III. It is seen here that the logarithms

TABLE III Overall Formation Constants of Fe (III)-EDTMP Complexes: Comparison with Literature Values

\begin{tabular}{|c|c|c|c|}
\hline \multirow[b]{2}{*}{ Complex } & \multirow[b]{2}{*}{ Species $m l h$} & \multicolumn{2}{|c|}{$\log \beta_{m l / h}$} \\
\hline & & This work ${ }^{a}$ & $19^{b}$ \\
\hline $\mathrm{FeL}(\mathrm{OH})$ & $11-1$ & 8.39 (9) & - \\
\hline $\mathrm{FeL}$ & 110 & 20.07 (5) & 19.60 \\
\hline FeLH & 111 & $26.56(6)$ & 26.74 \\
\hline $\mathrm{FeLH}_{2}$ & 112 & $31.65(6)$ & 33.02 \\
\hline $\mathrm{FeLH}_{3}$ & 113 & $36.12(7)$ & - \\
\hline
\end{tabular}

${ }^{a}$ Fitting 0.0233 ; number of points 114 ; values in parenthesis are standard deviations in the last significant digit.

${ }^{b} 5^{\circ} \mathrm{C}, I=0.1 \mathrm{M}\left(\mathrm{KNO}_{3}\right)$.
TABLE IV Formation Constants of Fe (III)-EDTMP Complexes (log $\mathrm{K}_{\text {mlh }}$ ): Comparison With Literature Values of Fe (III)-EDTA Complexes

\begin{tabular}{|c|c|c|c|c|c|}
\hline \multirow[b]{2}{*}{ Equilibrium quotient } & \multirow[b]{2}{*}{ This work } & \multicolumn{4}{|c|}{$\mathrm{Fe}(\mathrm{III})$-EDTA complexes $\left(\log \mathrm{K}_{m l l}\right)$} \\
\hline & & $\begin{array}{c}29 \\
(I=0)\end{array}$ & $\begin{array}{l}30 \\
(I=0.1 \mathrm{M})\end{array}$ & $\begin{array}{c}31 \\
(I=1 \mathrm{M})\end{array}$ & $(\mathrm{I}=\stackrel{32}{0.1} \mathrm{M})$ \\
\hline$[\mathrm{FeL}] /[\mathrm{Fe}][\mathrm{L}]$ & 20.07 & 24.23 & 23.75 & & 25.1 \\
\hline$[\mathrm{FeLH}] /[\mathrm{Fe}][\mathrm{HL}]$ & 15.23 & 16.26 & 14.59 & 15.2 & \\
\hline $\begin{array}{l}{\left[\mathrm{FeLH}_{2}\right] /[\mathrm{Fe}]\left[\mathrm{H}_{2} \mathrm{~L}\right]} \\
{[\mathrm{FeLH}}\end{array}$ & $\begin{array}{r}11.18 \\
8.54\end{array}$ & 8.72 & & & \\
\hline$[\mathrm{FeL}(\mathrm{OH})] /[\mathrm{FeL}][\mathrm{OH}]$ & 2.06 & & & 7.1 & 6.5 \\
\hline
\end{tabular}

of the normal chelate stability constant $\left(\beta_{110}\right)$ for the combination of the $\mathrm{Fe}^{3+}$ with an octanegative EDTMP anion $\left(\mathrm{L}^{-8}\right)$ are calculated as 20.07 at $25^{\circ} \mathrm{C}$. Because the stability is sufficited as 20.07 a solution of iron (III) chelate may be stored at a pH of about 11 for a number of weeks without developing any sign of the precipitation of ferric hydroxide.

As can be observed from Table IV, the formation constant of the normal chelate of $\mathrm{Fe}(\mathrm{III})$ with EDTMP $\left(\log \mathrm{K}_{110}=20.07\right)$ is much smaller than that of the EDTA chelate (log $\mathrm{K}_{110}=23.75-25.10$ ). This indicates that one of the nitrogen atoms of EDTMP is not engaged in coordination $^{33}$. As $\log \mathrm{K}_{110}=20.07>\log \mathrm{K}_{111}=15.23$, this suggests a very strong $\mathrm{Fe}-\mathrm{N}$ bond, which, in a protonation complex, cannot be ruptured. ${ }^{34}$ Consequently, the protonation of the FeL chelate occurs on the free oxygen atoms of the phosphonate groups of the complex.

The speciation diagrams (Figure 3 ) show that the FeL species exist in a great percentage in the $\mathrm{pH}$ range of 7-11. Therefore, in the basic range, most of the monoprotonated complexes undergo deprotonation:

$$
\mathrm{FeLH}^{4-} \rightleftharpoons \mathrm{FeL}^{5-}+\mathrm{H}^{+} \quad \mathrm{K}_{1}=\frac{[\mathrm{FeL}] \cdot[\mathrm{H}]}{[\mathrm{FeLH}]}=10^{-6.49}
$$

Analogically, the deprotonation of the two protonated Fe (III)-EDTMP chelates $\left(\mathrm{FeLH}_{2}\right.$ and $\left.\mathrm{FeLH}_{3}\right)$ can be written and calculated as follows:

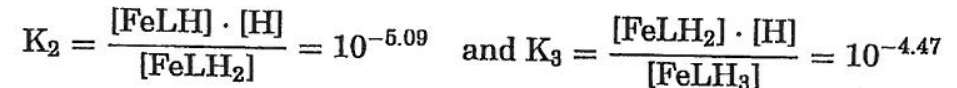

The fact that the first protonation constant of the complex $\left(\log \mathrm{K}_{1 \mathrm{p}}=\right.$ 6.49 ) is smaller than the second protonation constant of the ligand (log $K_{2}=9.14$ ) indicates that the first protonation occurs on the free atoms of the phosphonate groups of the complex. ${ }^{35}$ Similarly, the second 


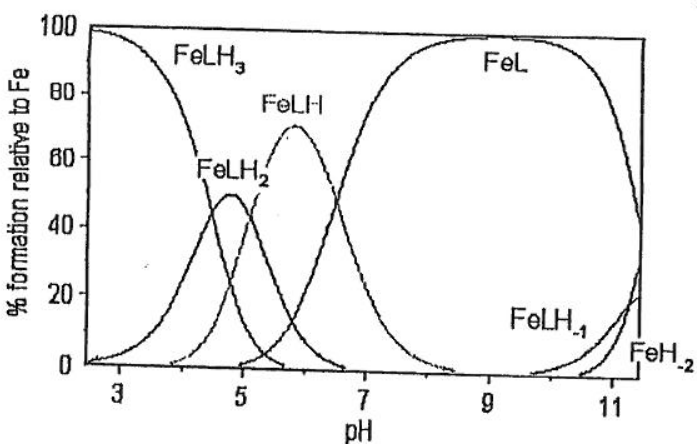

FIGURE 3 Speciation diagrams of the Fe (III)-EDTMP chelates, calculated for $\mathrm{C}_{\mathrm{L}}=0.001936 \mathrm{M}, \mathrm{C}_{\mathrm{Fe}}=0.000428 \mathrm{M}$, at $25^{\circ} \mathrm{C}$ and $\mathrm{I}=0.2 \mathrm{M}(\mathrm{NaCl})$.

protonation constant of the complex $\left(\log K_{2 p}=5.09\right)$ is smaller than the third protonation constant of the ligand $\left(\log K_{3}=7.44\right)$. For the third protonation process, $\log \mathrm{K}_{3 \mathrm{p}}=4.47$ is smaller than the fourth protonation constant of the ligand $\left(\log \mathrm{K}_{4}=6.06\right)$. From this it can be surmized that the second and third protonation of the Fe (III)-EDTMP complexes also occur on the free oxygen atoms of the (II)-EDTMP comof the complex.

The evaluation of the behavior of the ferric ion complexes of EDTMP for medical application cannot be made by stability constant values. In a blood stream, other species such as $\mathrm{Ca}^{2+}, \mathrm{Mg}^{2+} \mathrm{Zn}^{2+}$ andues. In present and may compete metal complex with other ligands, such as transferrin ${ }^{28}$ To avoid the transfer of the ferric ion to the biomolecule, which can be fatal if toxic or radioactive ions are used, the complex formed with to be particularly stable and highly selective $\mathrm{pF}$. $\left[\mathrm{Fe}^{3+}\right.$ free $]$ ), given in Table $\mathrm{V}$, are a more reliable choice for the evaluation of ligand effectiveness, especially when taking into account the protonation constants of the ligand at physiological $\mathrm{pH}(\mathrm{pH}=7.40)$ when the total ligand concentration is twice that of the total iron concentration.

Due to the dependence of $\mathrm{pFe}$ on the ligand protonation constants, very different predictions about in vivo stability can result if or $\mathrm{pFe}$ values are compared. The larger thosult if $\log \mathrm{K}_{\mathrm{i}}$ $100 \%$ excess of a free ligand at physio $\left.\mathrm{C}_{\mathrm{Fe}}=1 \cdot 10^{-5} \mathrm{M}, \mathrm{C}_{\mathrm{L}}=2 \cdot 10^{-5} \mathrm{M}\right)$ the more effective is the ligand. The relative order of the $\mathrm{pFe}$ values may change if a different conditions is used to calculate the $\mathrm{pFe}$ values. Moreover, for biological studies, the conditional stability constant of a metal chelate under
TABLE V pFe and Conditional Stability Constant $\left(\log \mathrm{K}_{\mathrm{FeL}}^{\prime}\right)$ at $25^{\circ} \mathrm{C}$ and $\mathrm{I}=0.2 \mathrm{M}(\mathrm{NaCl})$

\begin{tabular}{lccc}
\hline $\begin{array}{l}\mathrm{C}_{\mathrm{L}} \\
(\mathrm{mM})\end{array}$ & $\begin{array}{c}\mathrm{C}_{\mathrm{Fe}} \\
(\mathrm{mM})\end{array}$ & $\mathrm{pFe}^{a}$ & $\log \mathrm{K}_{\mathrm{FeL}}^{\prime}$ \\
\hline 1.928 & 1.784 & 13.04 & \\
1.928 & 0.856 & 14.19 & \\
1.928 & 0.428 & 14.69 & 14.12 \\
0.002 & 0.001 & 13.54 & \\
0.050 & 0.001 & 15.83 & \\
\hline
\end{tabular}

${ }^{a} \mathrm{pFe}$ values were calculated at physiological $\mathrm{pH}(7.4)$

physiological conditions $(\mathrm{pH}=7.4)$ is more important than the overall stability constant. ${ }^{36}$

Figure 3 shows that at physiological $\mathrm{pH}$, about $85 \%$ of ferric ion complexes of EDTMP, exist as normal FeL chelate and about $15 \%$ exist as a monoprotonated FeLH chelate. Table $\mathrm{V}$ contains the $\mathrm{pFe}$ values calculated for differ values constants can calculate the concentration of a free aqua ferric ion $\left[\mathrm{Fe}^{3+}\right]$ at any experimental point. In the titration data, the existence of the value of 7.4 for the $\mathrm{pH}$ is essential 7.4 for the $\mathrm{pH}$ is essential. However, the titration curves of mixtures Fe: $L$ in the $\mathrm{pH}$ domain of $6-9$ show no plateau, so the value 7.40 for the $\mathrm{pH}$ is almost impossible to attain. This is the primary reason for which computer program was used.16

In case side reactions occur in a solution, the value of the constant $\mathrm{K}_{\mathrm{ML}}$ is substituted by a conditional stability constant $K_{\mathrm{ML}}^{\prime}$ defined as $^{37}$ follows:

$$
\mathrm{K}_{\mathrm{ML}}^{\prime}=\mathrm{K}_{\mathrm{ML}} \cdot \frac{\alpha_{\mathrm{ML}}}{\alpha_{\mathrm{M}} \cdot \alpha_{\mathrm{L}}}
$$

where $\alpha_{\mathrm{M}}, \alpha_{\mathrm{L}}$, and $\alpha_{\mathrm{ML}}$ represent the side reaction coefficient of the metal ion, the ligand, and the formed complex. The $\mathrm{pH}$ value influences $\alpha_{\mathrm{M}}, \alpha_{\mathrm{L}}$, and $\alpha_{\mathrm{ML}}$, and the presence of other metal ions influences $\alpha_{\mathrm{L}}$. For the FeL chelate, a side reaction coefficient of normal chelate, $\alpha_{\mathrm{ML}}$. For be calculated as follows:

$$
\alpha_{\mathrm{FeL}}=1+\frac{\sum_{\mathrm{h}} \beta_{11 \mathrm{~h}} \cdot\left[\mathrm{H}^{+}\right]^{\mathrm{h}}}{\beta_{110}} \text { where } \mathrm{h}=-1,1,2 \text {, and } 3
$$

The side reaction coefficient for EDTMP is as follows:

$$
\alpha_{\mathrm{L}}=1+\sum_{\mathrm{i}=1}^{\mathrm{i}=6} \beta_{\mathrm{i}} \cdot\left[\mathrm{H}^{+}\right]^{\mathrm{i}}
$$


TABLE VI $\log \mathrm{IK}_{\mathrm{ML}}$ and $\mathrm{pM}$ Values for $\mathrm{Ca}^{2+}$ $\mathrm{Mg}^{2+}, \mathrm{Zn}^{2+}$, and $\mathrm{Fe}^{3+}$ Complexes of EDTMU $25^{\circ} \mathrm{C}_{\mathrm{L}}=0.002 \mathrm{mM}, \mathrm{C}_{\mathrm{M}}=0.001 \mathrm{mM}$, and $\mathrm{I}=0.2 \mathrm{M}(\mathrm{NaCl})$

\begin{tabular}{lrr}
\hline Cation & $\log \mathrm{K}_{\mathrm{ML}}$ & $\mathrm{pM}^{b}$ \\
\hline $\mathrm{Ca}^{2+}$ & $9.29^{a}$ & 8.05 \\
$\mathrm{Mg}^{2+}$ & $8.43^{a}$ & 8.57 \\
$\mathrm{Zn}^{2+}$ & $18.76^{a}$ & 12.76 \\
$\mathrm{Fe}^{3+}$ & 20.07 & 13.54 \\
\hline
\end{tabular}

Values from. ${ }^{22}$ (7.4)

${ }^{b} \mathrm{pM}$ values were calculated at physiological $\mathrm{pH}$

Because at $\mathrm{pH}<10$ the concentration of hydrolytic species of ferric can be ne-

In Table VI PM ,

In Table VI, $\mathrm{pM}$ values for $\mathrm{Ca}^{2+}, \mathrm{Mg}^{2+}$, and $\mathrm{Zn}^{2+}$ were calculated with the HySS program at $25^{\circ} \mathrm{C}, \mathrm{C}_{\mathrm{L}}=0.002 \mathrm{mM}, \mathrm{C}_{\mathrm{M}}=0.001 \mathrm{mM}$, and $\mathrm{I}=0.2 \mathrm{M}(\mathrm{NaCl})$ on the basis of the formation constant calculated by Motekaitis and colleagues. ${ }^{22}$ These results indicate that the competition among $\mathrm{Ca}^{2+}, \mathrm{Mg}^{2+}, \mathrm{Zn}^{2+}$, and $\mathrm{Fe}^{3+}$ with EDTMP is seen to favor $\mathrm{Fe}^{3+}$ at $\mathrm{pH}=7.4$. Therefore, the iron (III) complex should be stable enough to avoid interference by $\mathrm{Ca}^{2+}, \mathrm{Mg}^{2+}$, and $\mathrm{Zn}^{2+}$.

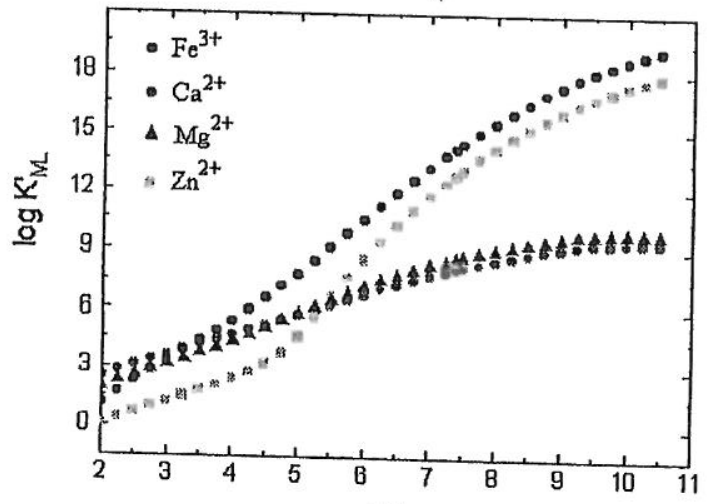

$\mathrm{pH}$ FIGURE 4 Variation of the conditional stability constants for $\mathrm{Ca}^{2+}, \mathrm{Mg}^{2+}$,
$\mathrm{Zn}^{2+}$, and $\mathrm{Fe}^{3+}$ complexes with EDTMP with
The $\mathrm{pH}$ dependence of the conditional stability constants for the 1.1 complexes of $\mathrm{Ca}^{2+}, \mathrm{Mg}^{2+}, \mathrm{Zn}^{2+}$, and $\mathrm{Fe}^{3+}$ with EDTMP is given in Figure 4. It is observed that for the entire $\mathrm{pH}$ domain however, for the pairs $\log \mathrm{K}_{\mathrm{FeL}}^{\prime}-\log \mathrm{K}_{\mathrm{CaL}}^{\prime}$ and $\log \mathrm{K}_{\mathrm{FeL}}^{\prime}-\log \mathrm{K}_{\mathrm{MgL}}^{\prime}$
there is the same inequality at $\mathrm{pH}>3.5$

\section{REFERENCES}

1] D. E. Reichert, J. S. Lewis, and C. J. Anderson, Coord. Chem. Rev., 184, 3 (1999),

2. L. Thunus and R. Lejeune, Coord. Chem. Rev., 184, 125 (1999).

[3] R. B. Lauffer, Chem. Rev., 87, 901 (1987).

[4] P. Caravan, J. J. Ellison, T. J. McMury, and R. B. Lauffer, Chem. Rev., 99, 2293 (1999).

[5] S. Aime, M. Botta, M. Fasano, and E. Terreno, Chem. Soc. Rev., 27, 19 (1998).

[6] S. Jurrisson, D. Berning, D. Jia, and D. Ma, Chem. Rev., 93, 1137 (1993).

[7] S. Aime, M. Botta, M. Fasano, S. G. Crich, and E. Terreno, Coord. Chem. Rev., 185-

Sauvage, and . Gilsaul, M. Hermann, V. Humblet, V. Jacques, M. Meshahi, C. A. Bianchi, J. F. Desreux, Coord. Chem. Rev., 185-186, 451 (1999).

and M. Virtuani, J. Chem Girgi, P. Losi, P. Mariani, P. Paoli, P. Rossi, B. Valtancoli,

[10] A. Bianchi, L Calahi, F. Coca, Dallon Trans., 697 (2000).

Valtancoli, C. Calahi, F. Corana, S. Fontana, P. Losi, A. Maiochi, L. Paleuri, and B.

G. Schwari, Coord Chen

(1945).

K. Sawada, T. Miyagawa, T. Sakaguchi, and K. Doi, J. Chem. Soc., Dalton TYans.,

13] K. Sawada, T. Sakaguchi, T. Suzuki, and H. Miyamoto, J. Solution Chem., 20, 829

14] E. Princz, K. Mogyorosi, and I. Labadi, Thermal Analysis Calorimetry, 77, 767 (2004)

15] L. Zekany and I. Nagypal, In Computational Methods for the Determination of Stability Constants, D. Leggett (Ed.) (Plenum Press, New York, 1985).

Rev, 184, 1. $\mathrm{S}$. Harned

17] H. S. Harned and B. B. Owen, The Physical Chemistry of Electrolytic Solutions, (Reinhold Publishing Corp., New York, 1958), 3rd ed., pp. 634-649, 762-754.

[18] M. D. Lind and B. Lee, J. Am. Chem. Soc., 87, 1611 (1965).

[19] S. Westerback, K. S. Rajan, and A. E. Martell, J. Am. Chem. Soc., 87, 2567 (1965).

M. I. Kabachnik, I. M. Dyatlova, T. A. Medved, Yu. F. Belugin, and V. V. Sidorenko, Proc. Acad. Sci., (USSR), 175, 621 (1967).

(21] Tinova, Radiokhimiya, 12, 519 (1970).

[23] E. N. Rizkallis, I. Murase, and A. E. Martell, Inorg. Chem., 25, 2303 (1976)

24] T. Tizkalla and M. T. M. Zaki, Talanta, 16, 507 (1979).

251 G. C. de Witt, P. M. Mayda, Bull. Chem. Soc. Japan, 70, 829 (1997).

J. Webb, and G. Hefter, Inorg. Chim. Acta, 275-276, 37

[27] R. J. Motekenbach and H. Ackermann, Helv. Chim. Acta, 31, 1029 (1948).

[27] R. J: Motekaitis, I. Murase, and A. E. Martell, J. Inorg. Nucl. Chem., 33, 3353 (1971). 
[28] B. Achour, J. Costa, R. Delgado, E. Garrigues, C. F. G. C. Geraldes, N. Korber F Nepveu, and M. I. Prata, Inorg. Chem., 37, 2729 (1998).

[29] M. Beck and S. Gorog, J. Inorg. Nucl. Chem., 12, 353 (1960).

30] N. Zhirnova and K. Astukhov, Zh. Phys. Khim., 41, 366 (1967).

[31] T. Bhat and D. Rahhamma, Indian J. Chem., 3, 151 (1965).

(32] E. Bottari and G. Anderegg, Helv. Chim. Acta, 50, 2349 (1967),

[33] W. Duan, H. Oota, and K. Sawada, J. Chem. Soc., Dalton Trans., 3075 (1999).

[35] K. Sawada, T. Araki, and T. Suzuki, J. Am. Chem. Soc., 26, 1199 (1987).

[36] K. Sawada, W. Duan, M. Ono, and K. Satoh, J. Chem. Soc., Dalton Trans., 919 (2000)

4113 (1998).
4 . H. Lee, G. C. Liu, and R. S. Sheu, J. Chem. Soc., Dalton Trans., 24,

[37] A. A. Amsheva, Zh. Anal. Chim., 33, 1054 (1978). 